\title{
特殊環境化での植物育成を可能とする インテリジェント生産検証システムの構築
}

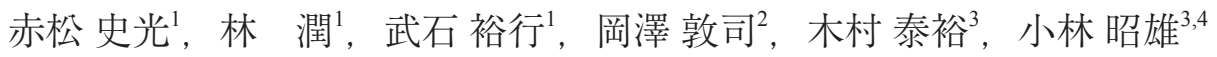 \\ ${ }^{1}$ 大阪大学大学院 工学研究科機械工学専攻 ( ₹565-0871 大阪府吹田市山田丘2-1) \\ ${ }^{2}$ 大阪府立大学大学院 生命環境科学研究科応用生命科学専攻 (599-8531 大阪府堺市中区学園町1-1) \\ ${ }^{3}$ 大阪大学 産業科学研究所新産業創成研究部門 ( T 567-0047 大阪府茨木市美穂 $个$ 丘8-1) \\ ${ }^{4}$ 大阪大学工学研究科付属サステイナビリティ・デザイン・オンサイト研究センター(660-0095 兵庫県尼崎市大浜町1-58-6)
}

\section{Design and Development of Intelligent Plant Growth System that Enables Growth Under Extreme Environmental Conditions}

\author{
Fumiteru AKAMATSU ${ }^{1}$, Jun HAYASHI ${ }^{1}$, Hiroyuki TAKEISHI ${ }^{1}$, Atsushi OKAZAWA ${ }^{2}$ \\ Yoshiaki KIMURA ${ }^{3}$, and Akio KOBAYASHI ${ }^{3,4}$ \\ ${ }^{1}$ Department of Mechanical engineering, Osaka University, 2-1 Yamadaoka, Suita, Osaka, 565-0871 \\ ${ }^{2}$ Department of Applied Life Sciences, Osaka Prefecture University, 1-1 Gakuen-cho, Nakaku, Sakai, Osaka 599-8531 \\ ${ }^{3}$ The Institute of Scientific and Industrial Research, Osaka University, 8-1 Mihogaoka, Ibaraki, Osaka, 567-0047 \\ ${ }^{4}$ On-site Research Center for Sustainability Design, Osaka University, 1-58-6 Oohama-cho, Amagasaki, Hyogo, 660-0095
}

(Received July 13, 2016)

\begin{abstract}
Plant growth is significantly affected by such environmental parameters as light, water, atmosphericcomposition and pressure, temperature, humidity, and nutrients. A higher growth rate for plants might be attained by modulating such environmental parameters, which also affect the plant's physiological responses and quality and quantity of metabolites. In this study, we designed and fabricated an environment-controlled chamber called a plant growing chamber (PGC) to offer a variety of growth conditions for plants. Our PGC modulates temperature, humidity, light intensity, light wavelength, air pressure, etc. Using it, we focused on atmospheric pressure to examine its effects on plant growth. We used an aquatic plant, Spirodela polyrrhiza, as a test plant and evaluated its growth rate under elevatedatmospheric pressure varying from 0.1 to $0.4 \mathrm{MPa}$. The effects of elevated pressure on the growth rate were analyzed by an imaging processor. The growth rate increased up to 1.25 times under $0.2 \mathrm{MPa}$, suggesting that photosynthesis can be improved under conditions of elevated pressure.
\end{abstract}

Key Words: Elevated pressure, Hyperbaric condition, Plant growing chamber, Spirodela polyrrhiza

\section{1. はじめに}

近年, 化石燃料の枯渇や地球温暖化をはじめとする環 境問題が地球規模の問題となっている。植物由来のバイ オマス燃料は, “再生可能な自然エネルギー”, “膨大な 資源量”、“カーボンニュートラル”といった利点がある ため, 化石燃料の代替燃料としてだけではなく，二酸化 炭素の大量排出による地球温暖化問題をも解決できる燃 料として注目されている。その一方で，植物由来のバイ オマス燃料は, “発熱量が低い”, “安定供給ができな い”，“コストが高い”などの問題点があるため，現在の ところ，大規模な普及には至っていない。 このうち， “発熱量が低い”, “安定供給ができない”といった問題 は，植物自体に由来する問題であり，これらの問題を解 決し，植物由来のバイオマス燃料をさらに普及させるた
めには，植物自体が潜在的に保持している特性を明らか にした上で，植物の持つ機能を増強する必要がある，植 物の持つ機能を増強する手法は, 遺伝子組換えを始めと して数多くの研究がなされているが, 我が国において は，遺伝子組み換え技術の普及には大きな障壁があるた めに，植物の持つ機能を増強する手法として，植物に環 境ストレスを加除する手法が着目されている ${ }^{1)}$.

環境ストレスを加除する手法とは，植物を育成する環 境の変化に対する植物応答を利用して植物自体を増強す る手法であり，植物の育成環境を人為的に制御すること で，植物の持つ機能を増強することができる。ここで, 植物応答を引き起こす環境因子のことを環境ストレスと いう。環境ストレスには，大分すると生物環境ストレス と物理化学的ストレスがある。生物環境ストレスとは病 原菌等から植物が攻撃を受けることに起因するストレス 
であり，物理化学的ストレスとは，主に水，温度，湿 度, 光, 圧力, 大気組成成分, 栄養分などが通常の状態 とは異なることに起因するストレスである。物理化学的 ストレスのうち，光ストレスを用いて植物の持つ機能を 増強する手法では, 短期間で植物全体の機能を増強する ことが可能であり，例えば，光ストレスにより，抗がん 剂の原料となるアルカロイド等の2次代謝産物を，植物 に多量に生成させることが試みられている22.

植物は数億年間の進化の過程で極めて多様な環境を生 き抜いてきた生物種である。したがって，潜在的に激し い環境変化に順応して生き延びるために必要な代謝系を 有していると考えられる。しかし，現存する植物では， 主として通常の環境下での生育に必要な遺伝子が発現し ていると推察される。植物の生育に関わる環境因子 (温 度, 大気成分, 圧力, 水分, 光等) を極限まで変動させ た場合，植物がいかなる反応を示すかを明らかにするこ とは, 植物生産能を高めるための知見を得るために重要 である ${ }^{3-5)}$. 植物の極限環境状態に対する応答の解析は, 任意の生育条件を設定できる植物育成チャンバーを設 計・製作することで達成できる。

本研究では, (1)圧力 (全圧, 二酸化炭素分圧, 酸素分 圧), (2)湿度, (3) 光 (光質 - 光量)，(4)温度などを任意 に可変できる植物育成チャンバーを設計・製作した。こ の植物育成チャンバーを活用することで，任意に環境制 御したチャンバー内での植物の生育や形態変化を観察で きると共に, 植物の質的な変化, つまり代謝物の変動や 遺伝子発現を解析することができる。 また, 通常発現し ていない遺伝子を同定し, 活用することで植物機能を向 上させることが可能となる。またその結果は，植物工場 等での閉鎖系における有用物質生産 (タンパク質, 脂質, デンブン, セルロース, ビタミン，フェノール性物質等) の生産効率を飛躍的に向上させる可能性に繋がる ${ }^{1,6)}$. さらに，バイオマス燃料として好ましい特性を有する植 物資源の生産 ${ }^{7-10)}$ ，並びに，宇宙空間における食物の自 給と酸素生産への適用も期待される ${ }^{11)}$.

本報では, 設計・製作した植物育成チャンバーの性能 を評価することに加えて, 同チャンバーを使用して, 圧 力環境に着目して植物の生育に与える影響を調べたので 併せて報告する。現在までに，低圧環境下で植物を育成 した際の植物応答に関する知見が報告されている ${ }^{12-14)}$. また，二酸化炭素濃度を上昇させた環境で植物を育成す ると, 光合成による二酸化炭素の吸収が促進されること が明らかとなっている ${ }^{16-18)}$. Andersen ${ }^{16)}$ は二酸化炭素 濃度が上昇すると，ウキクサの光合成量が増加すること を示した。一方で, 外部から二酸化炭素を供給し, 二酸 化炭素分圧を高めることに比べて, 全圧を高めることで 二酸化炭素分圧を高めることは容易である。また, 宇宙 空間では大気が存在しないため, 人工的に $0.1 \mathrm{MPa}(1$ 気 圧）の環境を生み出すことと, 加圧の環境を作り出すこ とは装置的には大差がなく, 全圧を高めることで効率的 に目的にあった植物を育成することができれば，将来的 には，宇宙開発においても有益な知見となる。すなわ ち，より少ないエネルギー投与量で効率的に植物を育成
できるか否かを検証し, 有用物質の生産性を高めること を可能とする装置の実現に資するデータを集積するため に，ウキクサ(Spirodela polyrrhiza)を用いて，大気を加 圧した条件下での育成結果についても併せて報告する。

\section{2. 対象植物および実験方法}

本実験では，ウキクサを対象植物として用いた。ウキ クサは，被子植物でありながら構造が単純で，小さな水 生植物であるために, 光や温度, 圧力などの環境因子の 制御がしやすい。ささらに増殖が速いために，実験での使 用に適した植物である。 また，全ての葉状体が水面上， すなわち同一平面上に浮揚するために葉面積の計測が容 易であるという利点がある.

ウキクサはハイポネックス (Hyponex: 10N-3P-3K0.05Mg-0.001Mn-0.005B, HYPONeX Japan, Co. Ltd.) を, 水道水で1000倍希釈した養液中で培養した，光源は蛍光 灯 $\left(27 \mathrm{~W}, \mathrm{OHM}\right.$ 製) であり，光量は $65 \pm 5 \mu \mathrm{mol} / \mathrm{m}^{2} \mathrm{~s}$ で 24 時間連続照射した。生育環境の温度は $22 \pm 2{ }^{\circ} \mathrm{C}$, 相対湿 度は70 $5 \%$ である (Table 1参照)。この条件で培養した ウキクサを高圧環境下で育成し，圧力に対する応答を観 察した。

高圧環境下でのウキクサの育成には，プラスチック製 容器(容量 $140 \mathrm{~mL}$, 縦 : $84 \mathrm{~mm}$, 横 : $59 \mathrm{~mm}$, 深さ : $32 \mathrm{~mm}$ ) を4つ用いた。容器にはそれぞれにハイポネックスを 1000 倍希釈した養液を $50 \mathrm{~mL}$ 加え, 培養容器中から無作 為に選定したウキクサを，それぞれ4株植え継いだ。

プラスチック製容器は，4台の植物育成チャンバーに 1つずつ設置した。プラスチック容器の設置位置は，植 物育成チャンバーの上部蓋から $155 \mathrm{~mm}$ の位置である. なお，植物育成チャンバーはプラスチック製容器を設置 する直前に $70 \%$ エタノールで殺菌した。柏木, 米谷 $\left.{ }^{19}\right)$ は ウキクサが光合成に必要な光量は60 $\mu \mathrm{mol} / \mathrm{m}^{2} \mathrm{~s}$ 程度であ ることを示し, 葉温が上昇すると光合成量が低下するこ とを示した。本研究では，葉温の上昇を抑制する目的 で，光量を $62 \pm 3 \mu \mathrm{mol} / \mathrm{m}^{2} \mathrm{~s}$ とた。 また，湿度を $60 \%$ に 制御した空気で，植物育成チャンバー内の空気を十分に 置換した。なお，光量は光量計(PHR-5101，T\&D製)を 用いて，チャンバー内の植物を設置する位置で計測し た。また, 湿度の計測は露点計(HMT-334, VAISALA 製)によって行った。なお, 本研究で使用した露点計は, 圧力の補正機能を保持しており，任意の圧力における湿 度を計測することができる，4台の植物育成チャンバー

Table 1 Common experimental condition.

\begin{tabular}{cc}
\hline Plants & Spirodela polyrrhiza \\
\hline Pressure $(\mathrm{MPa})$ & $0.1 \sim 0.4$ \\
\hline Light source & Fluorescent light \\
\hline Amount of Light $\left(\mu \mathrm{mol} / \mathrm{m}^{2} \mathrm{~s}\right)$ & $62 \pm 3$ \\
\hline Air temperature $\left({ }^{\circ} \mathrm{C}\right)$ & $22 \pm 2$ \\
\hline Medium & $\begin{array}{c}\text { Hyponex } \\
\text { (diluted state: } 1000)\end{array}$ \\
\hline Culture volume $(\mathrm{mL})$ & 50 \\
\hline Gas component & Air \\
\hline
\end{tabular}


内の圧力をそれぞれ，0.1から $0.4 \mathrm{MPa}$ に設定した。な

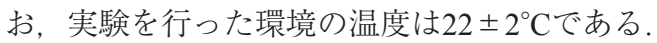

実験開始後，24時間毎に葉面積の計測を行った。ウキ クサの撮影は, 植物育成チャンバー上部よりデジタルカ メラ(DSC-HX5，SONY製)を用いて撮影した。撮影した 画像より, 画像処理ソフトを用いて葉面積を算出し, 葉 面積の増加率を用いて高圧環境が植物育成に与える効果 を相対的に評価した。な㧍，植物育成チャンバー内の空 気は実験開始から24時間毎に置換を行った。その際，植 物育成チャンバー内の圧力ははじめに設定した任意の圧 力を維持している.

\section{3. 結果および考察}

\section{1 植物の環境制御装置の開発}

様々な生育環境因子を変化させた場合の植物の応答を 観察するための装置を開発した。 以下に開発した装置の 詳細を述べる。

(1)植物育成チャンバーとガス供給システム

植物育成チャンバーのサイズは, 内径 $(\phi)$ が170 mm, 高さが $330 \mathrm{~mm}$ である，植物育成チャンバーは，上部と 側部をアクリル製とした。これは，植物の逐次観察が可 能かつチャンバー内に光を供給するためである，上部の

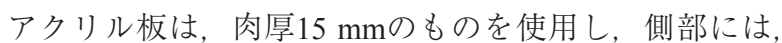
高速遠心注型成形により, 肉厚 $15 \mathrm{~mm}$ の中空円柱を形成 したアクリル円筒を使用した。 また，底面はペルチェ冷 却装置を用いて湿度制御を行うために，伝熱性能が高い アルミ板を使用した，な抢，アルミ板は半径方向に傾斜 を設けている。これは，ペルチェ冷却装置によって凝縮 した空気中の水蒸気を植物育成チャンバーの底面の中心 部分に収集するためである。 さらに，上部のアクリル板 抢よび下部のアルミ板には, 植物育成チャンバー内の圧 力の計測やガスの置換, 余剩水分を排出する目的で, 1/4 RTのねじ穴をそれぞれ3つずつ設けた。それらのね じ穴のうち, 上部の1つには圧力計 $(0.1 \sim 0.6 \mathrm{MPa}$ (Gauge), 長野計器製)を取り付け, 上部㧍よび下部の1つ には，開閉バルブ(SS42-GS4，Swagelok製）を取り付け， 他のねじ穴にはオスコネクター(SS400-1-4RT, Swagelok 製)を取り付けた。これらを Fig. 1に示すようにM10のボ ルトで連結した。 な押, 各部材の接合部には, ガスの漏 れを防ぐ目的で，オーリングが挟み込まれている.
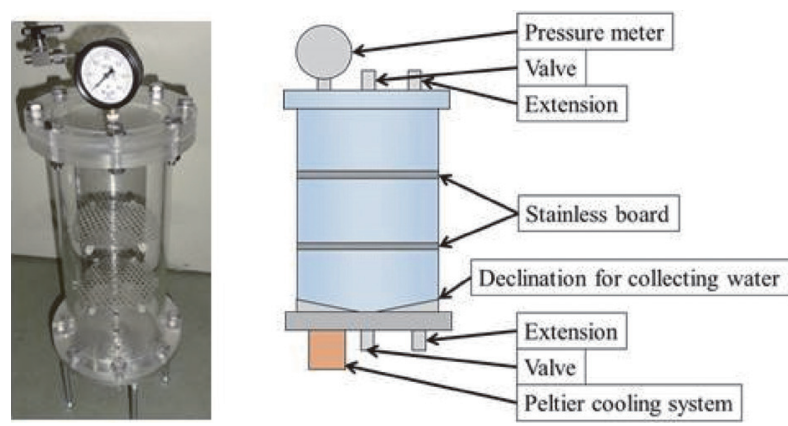

Fig. 1 Intelligent plant growth chamber.
ガス供給システムは, 上述の独自開発した植物育成 チャンバーに，圧縮空気ボンベ，レギュレーター(GF22510-RX-V，YUTAKA製)，クリーンフィルター(CF302，IAC製），開閉バルブ(SS42-GS4，Swagelok製），圧 カタンク $(10 \mathrm{~L}$ ，ユニコントロールズ製)，露点計(HMT334, VAISALA製)を、ステンレスチューブ(直径： $1 / 4$ inch, 肉厚 $1 \mathrm{~mm}$, Swagelok製) 㧍よび，フレキシブルチューブ (1/4 inch, 肉厚 $1.1 \mathrm{~mm}$, Swagelok製)により連結させて 構成した(Fig. 2参照)。本装置により, 最高で0.6 MPaの 高圧環境を実現することができる.

\section{(2)流入ガスの湿度制御}

気孔の開閉は植物の光合成・呼吸に必要な酸素や二酸 化炭素を, 細胞に行き渡らせるためのガス交換に重要な 機能である。この気孔の開閉は湿度条件に大きく左右さ れうる4)。そこで，異なる湿度条件での植物の高圧環境 に対する応答を観察するために, 流入ガスの相対湿度を 任意に制御することができる仕様とした。

高湿度環境を実現するために，ガスを供給する経路に 圧力容器 (容量 : $10 \mathrm{~L}$ ) を設置した. 圧力容器内には $1 \mathrm{~L}$ 程の蒸留水が溜められており, 供給ガスは圧力容器の底 部から供給されて蒸留水中でバブリングされることで, ガス中に水蒸気が供給される。 その結果, 装置を導入し ない場合の相対湿度は $5 \%$ 以下であるのに対し，この装 置を導入した系では，ガス流速を調節することで相対湿 度を35〜95\%の範囲で制御可能とした。

\section{(3) 光量制御}

前述のように, 本研究で作成した植物育成チャンバー は外部から光を供給できるように設計した，光源には蛍 光灯を用いて, 光量制御は植物育成チャンバーと光源と の距離を任意に調節することで $0 \sim 100 \mu \mathrm{mol} /\left(\mathrm{m}^{2} \mathrm{~s}\right)$ の範 囲で制御することを実現した，また，光質は使用する光 源を変更することにより制御することができる.

\section{(4) 温度制御}

初期状態の温度は流入させる気体の温度で決まる。ま たチャンバーの外気温度を制御することで, 植物チャン バー下部のアルミ板を通じて温度調節が可能である。

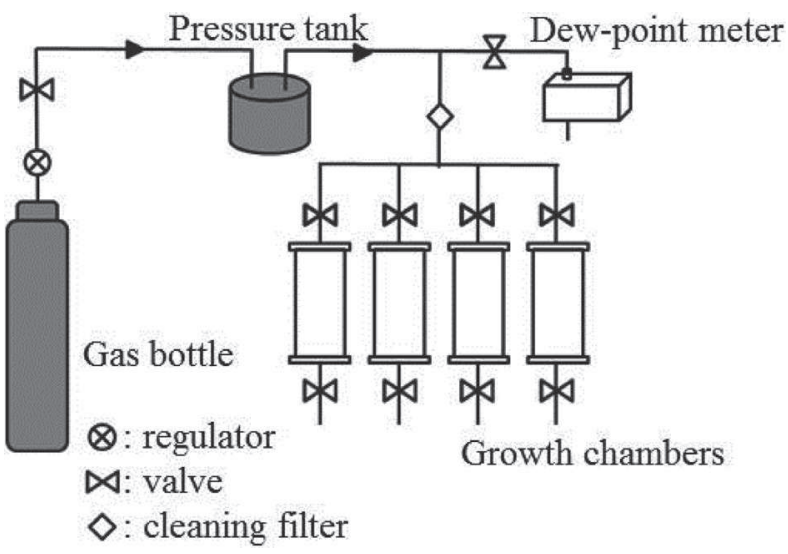

Fig. 2 Piping diagram of the plant growing system to regulate environmental parameters. 


\section{2 チャンバーの性能評価試験}

本実験では，製作したチャンバーの性能評価試験を実 施した．以下に実施概要と結果を示す.

本実験では，チャンバー内の環境を変化させた時の， 圧力, 気温, 湿度, 二酸化炭素濃度および酸素濃度の保 持能力を評価した。

\section{(1) 圧力変動の評価}

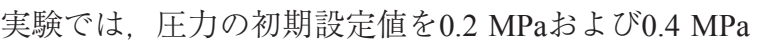
に設定し，チャンバー内の圧力を一定時間毎に計測し た。なお，実験で使用したガスは，圧縮空気(相対湿度 が5\%以下)拉よび，圧縮空気を圧力タンク内でバブリン グすることで，湿度を $80 \pm 5 \%$ まで昇させたガスであ る。 Fig. 3に，各圧力における，一定時間経過後のチヤ ンバー内の圧力值を示す．Fig. 3より，圧縮空気を使用 した場合は圧力変動が見られないことがわかる。一方 で，高湿度ガスを使用した場合は，時間が経過するに 従って圧力の変動が見られるが, その変動幅は初期圧力 の $\pm 5 \%$ 程度であり，十分に圧力を保持できていること がわかる．以上より，24時間経過した後も十分に圧力を 保持できていることが確認された.

\section{(2)二酸化炭素濃度変動の評価}

様々な濃度の二酸化炭素ガスを使用して，チャンバー の二酸化炭素濃度変動を評価した。チャンバー内の二酸 化炭素濃度は，実験開始直後および，24時間経過後にガ スクロマトグラフ $(\mathrm{CP} 4900, V a r i a n$ 製 $)$ を用いて分析し, 実験開始直後の二酸化炭素濃度からの変動を解析するこ とで，チャンバーの二酸化炭素を保持する能力を評価し た，各二酸化炭素濃度に対して4回ずつ実験を行い，4回 の平均值を解析結果とした。結果として, 二酸化炭素濃 度は最大で 16 ppm程増加した (Table 2参照)。変化率は最 大 $4 \%$ 程度であり, 本チャンバーは, 高濃度二酸化炭素 を使用した場合でも，十分にその環境を保持することが できた。

\section{(3)酸素濃度変動の評価}

空気を使用してチャンバーの酸素濃度変動を評価し

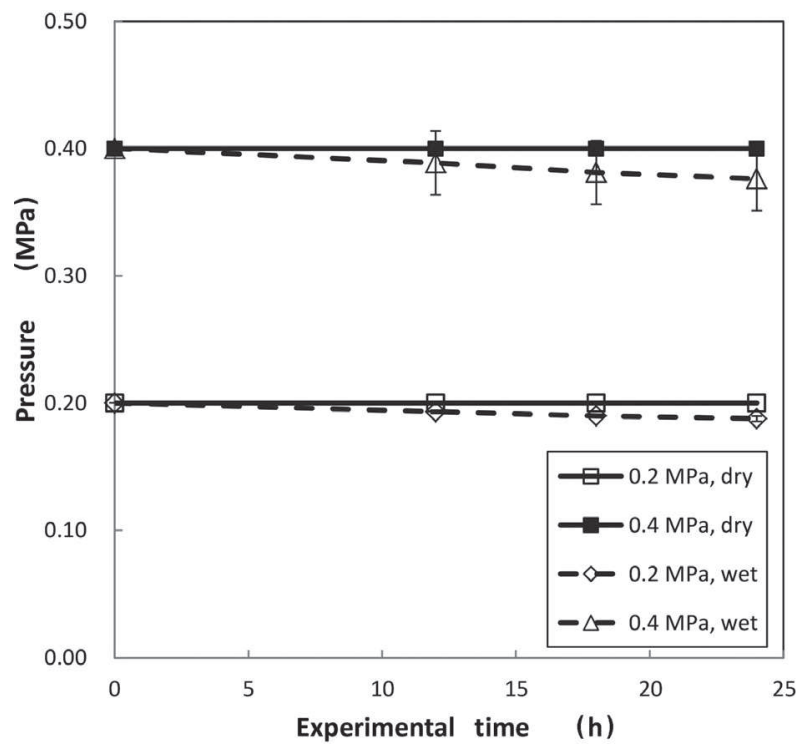

Fig. 3 Change of pressure with experimental time.
Table 2 Amount of $\mathrm{CO}_{2}$ concentration in the chamber at 0 and 24 hour and the changing rate.

\begin{tabular}{cccc}
\hline & \multicolumn{2}{c}{ Experimental time hour } & Changing rate \% \\
\cline { 2 - 4 } & 0 & 24 & - \\
\hline \multirow{2}{*}{$\begin{array}{c}\mathrm{CO}_{2} \\
(\mathrm{ppm})\end{array}$} & 429.2 & 445.5 & 3.8 \\
\cline { 2 - 4 } & 768.4 & 776.0 & 1.0 \\
\hline
\end{tabular}

た。チャンバー内の酸素濃度は，実験開始直後および， 24時間経過後にガスクロマトグラフ (CP4900, Varian製) を用いて分析し, 実験開始直後の酸素濃度からの変動を 解析することで, チャンバーの酸素濃度を保持する能力 を評価した。実験は4回行い，4回の平均值を解析結果と した。結果として，酸素濃度は20.72\%から $20.65 \%$ に変 化し，変化率は $0.36 \%$ 程度であった。このことから，本 チャンバーは，十分に酸素濃度を保持できることがわ かった。

(4) 温度・湿度変化の評価

実験では，チャンバー内上段，下段の温度，チャン バー内湿度，チャンバー外気温および，チャンバー外湿 度を一定時間毎に計測した。なお，計測には，デジタル 温湿度計を用いた。また，チャンバーは恒温室に設置さ れており，恒温室はエアコンによって $21^{\circ} \mathrm{C} に$ 制御されて いる. Fig. 4に実験結果を示す．Fig. 4より，チャンバー 内の気温は, チャンバー外気温に比べて, チャンバー下 段で $2^{\circ} \mathrm{C}$ ，上段で， $4^{\circ} \mathrm{C}$ 程度高くなることがわかる。これ は，チャンバー上段の方が，光源に近いためであると考 えられる。また，24時間でのチャンバー内の温度変化は $1{ }^{\circ} \mathrm{C}$ 未満であり，十分に温度が保持されていることがわ かる。

チャンバー内のチャンバー内の湿度は，24時間で最大 $4 \%$ 程度変動した。チャンバーの外部の湿度は $50 \%$ 程度 でチャンバー内湿度に比べて低いにもかかわらず，チャ ンバー内湿度は24時間にわかって大きな変動はないこと から，十分に保持できていることがわかる.

以上の実験結果より，本研究において設計，製作した チャンバーを使用して，十分に環境制御をすることがで

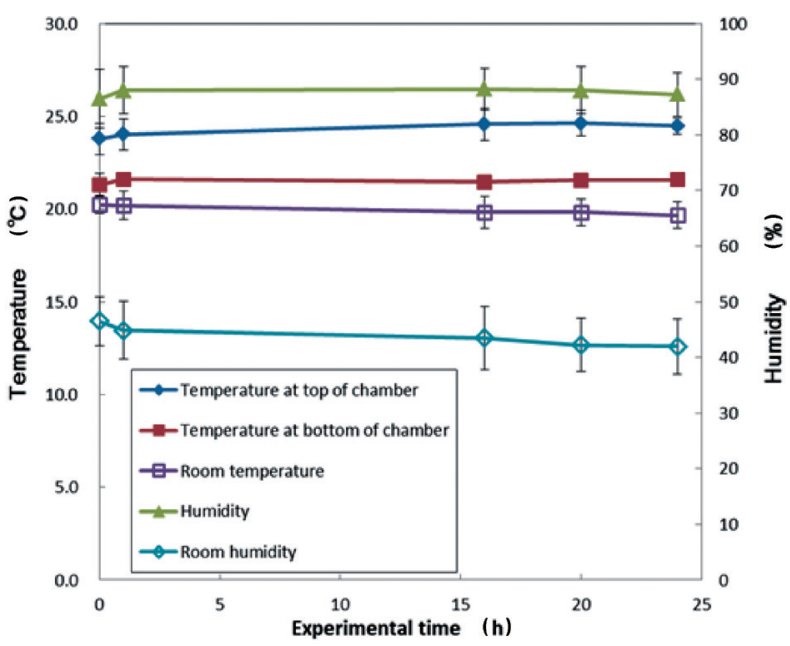

Fig. 4 Change of temperature with experimental time. 
きていることがわかる、本実験では，この環境制御シス テムを用いて, 圧力がウキクサの成長速度に与える影響 を評価した。

\section{3 ウキクサの育成掠よび成長速度の評価}

上記の装置(植物育成チャンバー)を用いて, 植物の高 圧環境への応答の1つとして, ウキクサの生育速度を検 証した，前述したように，ウキクサは増殖速度が速く，ま た葉状体が同一平面上に浮揚しているために計測が容易 である。ウキクサの生育状態は葉状体の総面積(葉面積 とする)抄よび葉状体数 (Frond number)で評価した20,21). 実験では24時間毎に葉面積を計測し, 生育初日からの増 加率で評価を行った。また，24時間毎に撮影したウキク サの画像より, ウキクサの葉状体数を求め, 各圧力によ る, 葉状体数に変化が生じるかどうかを検証した. 結果 として, 葉面積の増加率は圧力が $0.2 \mathrm{MPa}$ のとに最大 となり，常圧の場合の1.25倍であることが示された (Fig. 5参照).乙れは, 高圧環境下で育成することで二 酸化炭素分圧が高くなり, 光合成が促進されたためであ ると考えられる。

この結果は, 高圧環境下での植物育成の高効率化の可 能性を示している。 また, 各圧力における葉状体数の増 加率を算出したところ，0.4 MPaに扔いて，葉状体数が 低下する傾向が見られたが，0.3 MPaまでは，差は見受 けられなかった(Fig. 6参照)。このことから，0.3 MPa程 度の高圧環境では, ウキクサは良好な状態で育成するこ とができると思われるが，それ以上の高圧環境下では， 生育阻害が生じている可能性が示唆された。

\section{4. 結 論}

本研究では, 植物の潜在能力を開拓するために, 植物 育成システムの開発を行い，開発したシステムに打い て, 圧力, 湿度, 温度, 光量等を制御することを可能と した。また，本装置を用いて，ウキクサを高圧環境で育

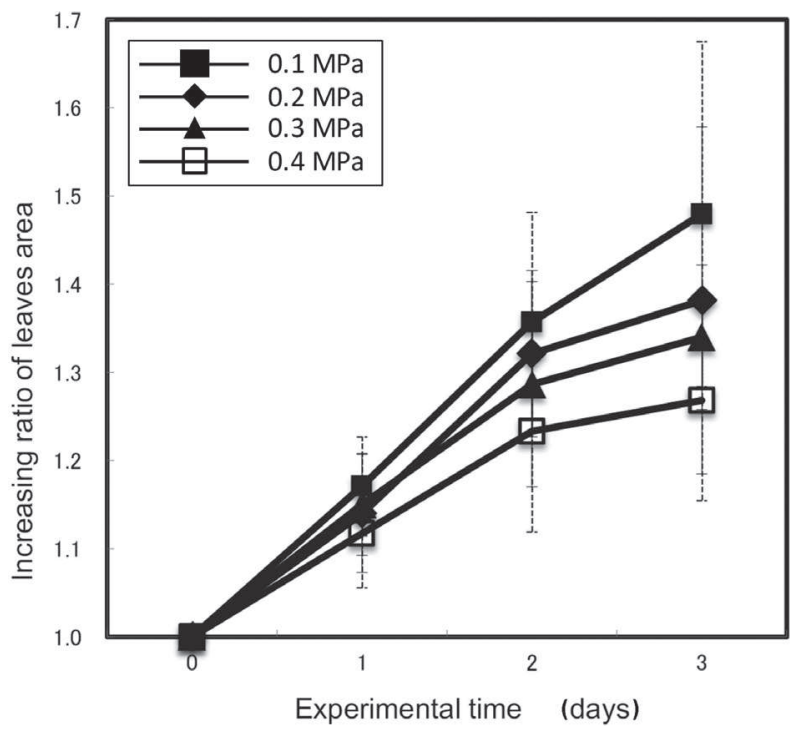

Fig. 5 Increasing ratio of leaves area at different pressure.

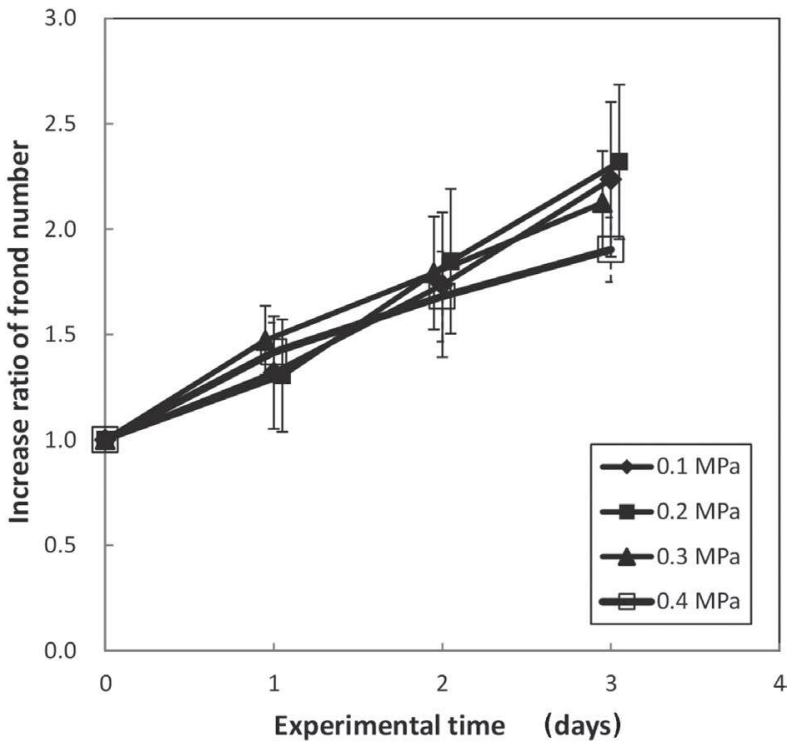

Fig. 6 Increasing ratio of frond number at different pressure.

成し，ウキクサの生育状態を検証した，その結果， $0.2 \mathrm{MPa}$ において，ウキクサの成長速度は最大となり，高圧環境 で育成することで，植物を高効率に育成できることが示 唆された，今後，細胞内構成成分の変化や光合成活性の 詳細を調べることで，増殖率向上の機構の解明が期待さ れる。

\section{参考文献}

1) T. Morimoto, T. Torii, and Y. Hashimoto: Control Eng. Practice 3/4 (1995) 505

2) M. Asano, K. Harada, T. Yoshikawa, T. Bamba, and K. Hirata, Biosci. Biotech. Biochem. 74 (2010) 384.

3) 横沢 正幸：日本土壤肥料学雑誌 74 (2003) 229 .

4) 久野春子, 新井一司：日本緑化工工学誌 28 (2002) 20.

5) H. Sasaki, M. Fukuyama, T. Onoue, T. Suyama, and T. Shoji: J. Grassland Science. 48 (2002) 12.

6）高山 真策, 米良 信昭, 秋田 求：植物環境工学 24 (2012) 224.

7）農林水産省農林水産技術会議事務局(編)：バイオマス変換 計画光琳 103 (1991)

8）小宮山宏，迫田 章義，松村幸彦：バイオマス日本 130-135 (2003) 152 .

9）赤松史光，林 潤，小林 昭雄：機械工学を生かしたイン テリジェントバイオマス生産検証システムの構築, 第6回 バイオマス科学会議発表論文集 (2011) 6 .

10）環境省地球環境局：事業者からの温室環境効果ガス排出量 算定方法ガイドライン (2003) 43 .

11）橋本 博文：日本惑星科学会誌 20 (2011) 125.

12) H. L. Gohila, R. A. Bucklina, and M. J. Correll: Advances in Science Research. 45 (2010) 823.

13) E. Goto, H. Ohta, K. Iwabuchi, and T. Takakura: J. Agric. Meteorology, 52 (1996) 117.

14) Y. Tanga, S. Guo, W. Dong, L. Qin, W. Ai, and S. Lin: Advanced in Space Research 46 (2010) 751.

15) 石神 靖弘, 後藤 英司：低圧環境における植物の生育. 植物 環境工学 20 (2008) 228 .

16) I. H. Andersen, C. Dons, S. Nilsen, and M. K. Haugstad: Photosynthesis Res. 6 (1985) 87.

17) H. Poorter: Plant Ecol. 104/105, 77, 1993.

18) W. J. Arp: Plant Cell Environ. 14 (1991) 869.

19) 柏木 良明, 米谷俊彦：地理学評論 66A（1993） 235.

20）後藤 英司：アグリフォトニクス一LEDを利用した植物工場 をめざして一，CMC出版（2008） 111.

21) W. S. Hillman: Botanical Review 27 (1961) 221. 